\author{
Agnieszka Izdebska \\ Katedra Teorii Literatury \\ Wydział Filologiczny \\ Uniwersytet Łódzki \\ e-mail: agnieszka.izdebska@uni.lodz.pl \\ ORCID: 0000-0002-6253-8397
}

\title{
W ciemni Susan Faludi - opowieść o wyprawie do „pomiędzy”
}

W ciemni, wydaną w 2016 głośną książkę ${ }^{1}$ Suasan Faludi można bez wątpienia wpisać w ramy konwencji gatunkowej, którą G. Thomas Couser określa jako filial narratives. Autor definiuje to pojęcie bardzo szeroko jako wszelkie niefikcjonalne opowieści dzieci o swoich rodzicach, najczęściej będące rekonstrukcją ich biografii ${ }^{2}$. Couser w swojej książce próbuje, między innymi, odpowiedzieć na pytanie, dlaczego dużo częściej bohaterami tych tekstów są ojcowie, rzadziej matki. Dochodzi do wniosku, że w patriarchalnych rodzinach, których w większości te opowieści dotyczą, to właśnie ojcowie byli bardziej enigmatycznymi, mniej dostępnymi bądź nawet nieobecnymi rodzicami i stąd dążenie dzieci, by dowiedzieć się, kim, tak naprawdę, byli ${ }^{3}$. Nie bez powodu zatem opowieść Faludi otwiera zdanie:

W lutym 2004 roku rozpoczęłam śledztwo, którego przedmiotem był ktoś, kogo ledwie znałam - mój ojciec. Projekt ten miał swoje źródło w urazie - urazie

\footnotetext{
1 Książka zyskała prestiżową (i bardzo wysoką) nagrodę magazynu Kirkus Reviews w dziale literatury non-fiction i znalazła się na liście finalistów Nagrody Pulitzera. Sama autorka została nią nagrodzona w 1991 roku.

2 Zob. G.Th. Couser, Memoir: An Introduction, Oxford 2012, s. 154.

3 Tamże, s. 154-155. Nawiasem, Couser przywołuje wspomnienia córki J. D. Salingera, Margaret, Dream Cutcher, wydane w 2000 roku. W tym wypadku bohater opowieści jest podwójnie tajemniczy ze względu na decyzję pisarza, by pędzić życie eremity. Salinger zerwał zresztą kontakty z córką, gdy dowiedział się, że zamierza opublikować książkę [s. 158].
} 
córki, której ojciec zniknął z jej życia. Byłam na tropie beztroskiego przestępcy, zręcznego oszusta, któremu udało się uciec od tak wielu rzeczy: zobowiązań, uczuć, winy, skruchy. Przygotowywałam akt oskarżenia, gromadząc materiał dowodowy do procesu. Niemniej w pewnym momencie oskarżycielka stała się świadkinią. Nie było jednak jasne, czego właściwie byłam świadkinią ${ }^{4}$.

Dociekania autorki zaczynają się od wiadomości mailowej, w której ojciec zawiadamia ją, że poddał się operacji zmiany płci - zatem ich przedmiotem będzie zarówno Steven Faludi, jak i Stefánie, a jak się potem okaże również István Friedman. Wszystkie te wcielenia zdają się trwać w płynnej, niepewnej relacji wobec siebie - choć Stefánie powie o nich twardo „To już nie jestem ja" [s. 75].

Od razu zatem zostaje dookreślony kontekst emocjonalny tej opowieści - uraza opuszczonego dziecka, niepewnego tego, kogo właściwie utraciło i kogo w związku z tym tropi. Autorka zamknie tę historię uwagą, że jej relacja $z$ ojcem nie zaowocowała zawarciem pokoju, najwyżej kruchym rozejmem, który ponownie przerodził się w spór. W finale opowieści odnajdziemy jednak przede wszystkim współczucie obejmujące wszystkie wcielenia ojca Faludi. Tym samym, oczywiście, bohaterem $W$ ciemni jest tyleż niesforny uciekinier, co i ściągająca go córka: to z jej perspektywy konstruowana jest ta opowieść $\mathrm{i}$ to jej emocjonalne relacje $\mathrm{z}$ ojcem bywają tu przedmiotem przedstawienia.

Metafora pogoni, podążania czyimś tropem („Obsadziłam się w roli jednoosobowej obławy, tropiącej liczne jaźnie mojego ojca w ich sekretnych kryjówkach" [s. 9]) będzie się przewijać przez całą historię budowaną przez Faludi. Ostatecznie, w pewien sposób domknie tę historię śmierć ojca, w inny - książka mu poświęcona. Steffi, jak będzie o sobie mówić dawny Steven Faludi, przeczytawszy ją, stwierdzi: "Cieszę się. Wiesz o moim życiu więcej niż ja”, a córka dopowie: „Ten jeden raz mój ojciec był zadowolony z tego, że został złapany, nawet jeśli tylko na papierze" [s. 10]. Zatem, jak się może wydawać, ostatecznie obława dopada zbiega. Ale kogo właściwie?

Steven Faludi był węgierskim Żydem, który dorastał w Budapeszcie, gdzie spędził wojnę. Tam też, w 1944 roku, przeżył falę deportacji do Auschwitz i Birkenau całej społeczności żydowskiej i udało mu się ocalić od wywózki własnych rodziców. Po 1945 wyjechał do Brazylii i Stanów Zjednoczonych, by ostatecznie, po transformacji lat 90. wrócić do swego rodzinnego miasta i tam dokonać życia jako Stefánie. Rodzic autorki - jak wypada go nazywać - był artystą, wielbicielem sztuki filmowej i fotografii, ale przede

\footnotetext{
4 S. Faludi, W ciemni, przeł. J. Bednarek, Warszawa 2017, s. 9. Kolejne cytaty lokalizuję w tekście głównym.
} 
wszystkim mistrzowsko dokonywał retuszy. Tak córka opowiada o jego amerykańskich latach:

Pracował wtedy w ciemni w mieście, dojeżdżając do pozbawionej okien komnaty. [...] Spędzał dnie w akwaryjnym mroku [...] zaciemniając, rozświetlając i manipulując, sprawiając, że znikały części ciała, budynki i całe krajobrazy. Osiągał w medium fotografii to, o czym sądził, że jest możliwe tylko w filmie: sprawiał, że historia miała taki kształt, jak chciał [s. 42].

Jego współpracownik, dyrektor działu produkcji artystycznej Condé Nast, powie o nim po latach: „To było niesamowite. Nigdy nie dało się odkryć, co zostało zmienione. Nie dało się odróżnić oryginału od kopii" [s. 43]. Zatem Faludi ściga manipulatora, kreatora, ale też kogoś, kto działa w ukryciu, $\mathrm{z}$ dala od światła, pozostaje w mroku. Nawet, jeśli się stamtąd wyłaniał, zdaniem córki pozostawał postacią enigmatyczną - tak komentuje filmy, które ojciec kręcił utrwalając na taśmie sceny $\mathrm{z}$ ich życia rodzinnego i sam w nich uczestniczył:

Nigdy nie był bardziej nieobecny niż podczas tych krótkich chwil, gdy pojawiał się na ekranie, otoczony rekwizytami swojej amerykańskiej rodziny, odgrywając przed kamerą prywatną tożsamość, przekształcając się, klatka po klatce, w mężczyznę, którego historia została zastąpiona obrazem - obrazem przedstawiającym nikogo, kogokolwiek [s. 42].

Zjawisko intensywnej obecności ojca w życiu jego amerykańskiej rodziny, a jednocześnie swoista nieobecność, niejako wyretuszowanie się, bycie pustym miejscem po kimś, fascynuje zarówno córkę, jak i żonę:

Wydawał się bezustannie zakonspirowany, ukryty za wybudowanym przez siebie murem, obserwując przez umieszczone w nim lustro weneckie. [...] Mimo swej agresywnej dominacji pozostawał w jakiś sposób niewidzialny. „Jest tak, jakby go tu nigdy nie było", powiedziała do mnie moja matka w dniu, który nastąpił po nocy, kiedy opuścił nasz dom na dobre, po dwudziestu latach ich małżeństwa [s. 16].

Córka dopowiada: „Wydawało mi się, że zawsze był właśnie taki: nieodgadniony i niestabilny, czarna skrzynka i detonator, na przemian odległy i natrętny" [s. 22].

Tytułowa metafora ciemni sugeruje, że część opowieści będzie dotyczyć owej przestrzeni, w której ukrywając się, Steven/Stefánie stwarza światy i samego/samą siebie. Jednocześnie nawiązuje do jednego $\mathrm{z}$ aspektów relacji między autorką a przedmiotem jej dociekań. Otóż ojciec daje jej kiedyś radę, by została - jak on - retuszerką fotografii. Faludi komentuje: 
Była to dziwna rada dla córki, której obsesją od pierwszego dnia, gdy dołączyła do zespołu redakcyjnego gazetki wydawanej przez jej podstawówkę, było wydobywanie skaz i błędów na powierzchnię, a nie ich ukrywanie. Przez cały czas, gdy się do siebie nie odzywaliśmy, i tym bardziej czas, gdy znów zaczęliśmy rozmawiać, w samym sercu łączących nas relacji tkwił konflikt między wymazywaniem i ujawnianiem, między pędzelkiem retuszera i notesem reporterki, miedzy mistrzem maskowania i uczennicą, która chciała go zdemaskować [s. 43-44].

Ta kontrowersja, o której pisze Faludi, wynika też z fundamentalnych różnic między obojgiem protagonistów: "O ile ojciec fotograf wolał obraz, o tyle córka dziennikarka wolała słowo" [s. 25]. Najwyraźniej w jej mniemaniu obrazy w rękach genialnego retuszera - i jak się okaże mistrzyni Photoshopu tracą swą moc świadectwa, stają się niewiarygodne jako dowód w śledztwie 5 .

Ów konflikt tkwiący $u$ podstaw relacji z ojcem zdaje się czasami przeradzać w kampanię wojenną. To, że autorka tak postrzega ów proces widać na retorycznym poziomie opowieści. Gdy córka wita się z ojcem na lotnisku w Budapeszcie, widząc go po raz pierwszy po tranzycji, wymienia z nim uścisk i doświadcza niezwykłego doznania: „Jej piersi [...] zderzyły się z moimi. Twarde, sprawiały wrażenie nie tyle części ciała, co fortyfikacji” [s. 30]. Kiedy już w domu Stefánie usiłuje gwałtownie oswoić córkę ze swoim nowym ciałem, ta komentuje: „Jej pokazy zaczęły przypominać inwazję" [s. 68]. Nawiasem, w jednym z wywiadów, jakich udzieliła po wydaniu $W$ ciemni, Faludi określa tożsamość jako pole bitwy ${ }^{6}$. W innej wypowiedzi, telefonicznej rozmowie z Marylynne Pitz, mówi też, że przy pisaniu książki pomagała jej rola dziennikarki, która dawała jej złudzenie dystansu i w którą wchodziła dla obrony, by nie zostać trafiona „psychologicznymi szrapnelami” ciskanymi

\footnotetext{
5 W tym kontekście interesująca jest kwestia decyzji Faludi, by nie włączać w tekst żadnych zdjęć. Jedna z recenzentek książki, Jane Sunmer komentuje ten fakt, uznając to za niefortunne pominięcie: „Strangely, the only picture I've seen of Stefanie, who died in May 2015 at 87, is on The Guardian website. Perhaps the author wanted her words to be the lens through which we view her enigmatic, complex though ultimately endearing father, but for a frustrated filmmaker, whose career was images, the lack of family photos seems an odd omission" [https: //www.dallasnews.com/arts/books/2016/07/15/susan-faludis-darkroom-provides-stunninglook-complex-man-became-woman-also-father, dostęp 27.08.2019]. Co ciekawe, brytyjskie wydanie, z którego pochodzą cytaty w tym artykule, fotografie zawiera. Mają one najwyraźniej status ilustracji i - choć bez wątpienia ich pojawienie się wymagało decyzji autorki - to za ich dobór odpowiedzialne jest wydawnictwo. Tym samym, mamy tu właściwie do czynienia z dwoma różnymi tekstami. Różnice między nimi to zagadnienie wymagające poświęcenia mu osobnego artykułu.

${ }^{6}$ http://signsjournal.org/in-the-darkroom/ [dostęp 20.08.2019]; Marcie Bianco, autorka artykułu poświęconego książce Faludi, cytująca jej wypowiedzi z wywiadu, który z nią przeprowadziła dla pisma "Salut", tytułuje swój tekst Identity Is a Battlefield - And Always a Negotiation.
} 
w nią prze ojca7 ${ }^{7}$ W pewnym aspekcie zatem $W$ ciemni jest sprawozdaniem z pola bitwy, nie tylko opowieścią o tropieniu niefrasobliwego zbiega. To również determinuje w pewnym stopniu kontekst emocjonalny, w jakim Faludi osadza swoją opowieść.

Mimo nalegań ojca, by pisała książkę o nim, Faludi wcale nie jest pewna, jakie są intencje ściganego. Gra w „wymazywanie i ujawnianie” toczy się intensywnie po przyjeździe do Budapesztu, gdy córka odwiedza go w nowym domu:

jednak w obrębie swoich murów ojciec usiłował z uporem czy wręcz desperacją wyjść z ukrycia. Albo przynajmniej pokazać jeden z aspektów swojego ja [...]. Przedstawiała mi się "Stefi", jak siebie nazywała, ukazując dowody istnienia tego, co nazywała „swoją nową tożsamością”. Włącznie, a nawet szczególnie, z dowodami na istnienie nowego ciała. [...] Jej pokazy zaczęły przypominać inwazję. [...] w miarę, jak przedstawienie gromadziło się kolejnymi warstwami, moja nieufność rosła. Co znajdowało się za zasłoną tej nowej otwartości? [s. 68]

Gdy Stefi wpada w negliżu do pokoju córki, w tej budzi to irytację, ale przyznaje: „wyczuwałam, że nie jestem celem agresji; albo, jeśli tak było, występowałam tylko w roli lustra" [s. 77]. Ciągle jednak pozostają zagadkowe intencje rodzica:

Jak to możliwe, że ktoś zapięty pod szyję, chce, żeby go rozpinać? Jeśli rzeczywiście tego chciała... Wszystkie te demonstracje i odkrycia ślizgały się, dosłownie na powierzchni. Następne dni upłynęły również pod znakiem powierzchni i ulotności: nadal oglądałam sukienki w jej szafach, bieliznę w szufladach [...] wszystkie sekrety z jej licznych gabinetów osobliwości. Nie mogłam odgadnąć, czy myślała, że ujawnia sekrety, czy tez odwraca moją uwagę od prawdziwych tajemnic. Patrz na mnie, ale nie patrz. Jako córka fotografa wiedziałam, że wpuszczenie światła do ciemni może ukazać materiał dowodowy albo go zniszczyć [...]. Mój ojciec i ja toczyliśmy bitwę o czas, przeszłość i przyszłość. Ona chciała, żebym podziwiała dekoracje na nowej wystawie Stefi. Ja chciałam poznać zawartość kolejnej zamkniętej komnaty [...] [s. 77].

Ta bitwa rozgrywa się w miejscach, w których - z czego Faludi zdaje się sobie doskonale sprawę - István/Steven/Stefánie/ojciec/rodzic konstruuje siebie,

7 „It allowed me to create the illusion of some distance. When things got really rocky, I could retreat to my dance as a reporter, asking questions and clutching my reporter's notebook like a baby bottle. As a journalist, you are often in situations where people are really impossible or are annoying or won't answer your questions or hostile. Going back into that guise allowed me not to take some of the psychological shrapnel my father was throwing at me" [https: //www.post-gazette.com/ae/books/2018/02/20/Susan-Faludi-Steven-Faludi-Stefanie-FaludiIn-the-Darkroom/stories/201802190009, dostęp 19.08.2019]. 
swoją tożsamość, uznając je za "rodzime”, „własne”. A właściwie należało by dopowiedzieć, że tyleż w owych miejscach, co i poprzez nie. Zatem córka usiłuje podążać za tą kreacją, odnotowując role, jakie pełnią w niej kamper ojca, jego dom, Budapeszt - wreszcie Węgry. Poznanie owej przestrzeni ma być zatem etapem śledztwa:

W miarę jak wjeżdżaliśmy na wzgórza Budy, myślałam: jestem w mieście będącym kuźnią młodości mojego ojca, kowadłem, na którym wykuty został jego charakter. Obecnie stało się ono sceną jej niezwykłego powrotu. Bliskość tych dwóch rzeczy sprawiła, że dziwnie się czułam. Przez całe życie miałam do czynienia z mężczyzną pozbawionym kontekstu. Teraz poznałam kontekst - ale tego mężczyzny już nie było [s. 36].

Mimo to, Faludi zdaje się łudzić się, że poznanie tego przestrzennego kontekstu pozwoli jej poznać nowe wcielenie mężczyzny - Stefánie ufortyfikowaną własnym biustem.

Kiedy zatem odwiedza ją w rodzimej - cokolwiek to będzie znaczyło przestrzeni, okazuje się, że jeździ ona po Budapeszcie ogromnym kamperem. Gdy córka widzi samochód po raz pierwszy, komentuje: „Wyglądał jak statek zacumowany na parkingu, jak piramida na kołach" [s. 31] ${ }^{8}$. Pojazd jest tak duży, że trudno go gdziekolwiek zaparkować, z mozołem przeciska się przez wąskie uliczki Budy, nie mieści się w garażu. Kiedy ruszają spod lotniska, przy wycofywaniu się z miejsca parkingowego, nieomal wpadają na samochód z tyłu - projektanci ogromnego kampera zapomnieli bowiem o tylnej szybie - "malutkie okienko nad siedzeniem ukazywało tylko niebo" [s. 32]. W drodze do domu, gdy jadą po słynnym Moście Łańcuchowym, Stefánie wspomina, że gdy jeździła po nim jako mały chłopiec, niemieckie dzieci krzyczały za nią "Hej, ty śmierdzący Żydku!”. I dodaje „to była tylko taka głupota”. „«Nie brzmi, jakby to była...» zaczęłam. «Patrzę w przyszłość, nie przeszłość», powiedziała Stefánie. Pomyślałam, że to dobre hasło dla kierowcy pojazdu bez tylnej szyby" [s. 34]. Ten kuriozalny zikkurat na kołach to jeden z przejawów pewnej ostentacji, z jaką Stefánie objawia siebie światu - siebie nową, już teraz damę, której wolno więcej niż poprzedniemu wcieleniu, ciągle w kokonie męskiej roli. Jednocześnie to sygnał swoistego nieprzystawania Stefi do zewnętrznych porządków, lekceważenie realiów przy kreowaniu własnych iluzji.

\footnotetext{
8 Wersja oryginalna brzmi: „It looked like a cruise ship beached in a parking lot, a ziggurat on wheels" [S. Faludi, In the Darkroom, London 2017, s. 24]. "Ziggurat" w stosunku do "piramidy" ma nieco inne, „mocniejsze” konotacje.
} 
Kolejnym miejscem, poprzez które Faludi postrzega Stefánie, jest jej dom. Jego opis to kolejny wyraz ambiwalentnego stosunku córki do sposobu, w jaki jej rodzic buduje swoje otoczenie:

Kamper z trudem pokonał ostatnie wzniesienie i ostry zakręt. Przed nami pojawił się dom, trzypiętrowa betonowa willa. [...] Teren otaczało ogrodzenie zabezpieczające, zaopatrzone $\mathrm{w}$ zamykaną bramę $\mathrm{z}$ alarmem. [...] Nie byłam pewna, czy ta forteca jest wyrazem nadmiernej czujności ojca, czy kultury, do której powrócił [s. 45].

Faludi przywołuje jako kontekst komentarz Colina Swatridge'a z czasów jego pobytu w Budapeszcie w latach 90. Zauważa on: „To, co charakterystycznie węgierskie $w$ owych podmiejskich domach, kiczowatych zamkach [...] jest właśnie połączenie ekshibicjonizmu z systemami ochrony" [s. 46]. Jak pisze dalej Faludi: „Dom ten okazał się katastrofalnym zbiorem partackich i nieukończonych rozwiązań budowlanych. [...] Potrzeba było niemal całego roku [...], by dom nadawał się do zamieszkania" [s. 52]. Zanim obie wejdą do wnętrza, Stefánie musi uruchomić i wyłączyć rozliczne alarmy i zabezpieczenia, wymagające respektowania skomplikowanego porządku, w którym gospodyni nieco się gubi.

Niebawem okaże się, że Stefánie nie jest skłonna wyruszyć z córką na zwiedzanie miasta, by pokazać jej miejsca, w których dorastała. Uważa, że to nudne, nadto dotyczy kogoś, kogo już nie ma. Faludi odnotowuje swoje narastające napięcie i postępującą klaustrofobię, frustrację odcięciem od świata na zewnątrz:

Zaczynałam się zastanawiać, czy zaawansowany system ochrony ma powstrzymać włamywacza przed wdarciem się do domu czy gości przed ucieczką. Brama była zamknięta $\mathrm{z}$ obu stron. Żeby wyjść $\mathrm{z}$ domu, musiałam ją prosić o klucz. Przebywanie w twierdzy Stefánie zaczęło przypominać uwięzienie w zamku Drakuli [...] [s. 67].

W zamkniętej przestrzeni domu córka nie tylko doznaje inwazji nowego wcielenia swojego ojca, w całej jego intensywnej, niedającej się wziąć w nawias kreacji. Zostaje też zaproszona do towarzyszenia Stefi w jej „elektronicznej stacji dowodzenia", nowszej wersji nowojorskiej ciemni, gdzie Stefánie "trollowała w blogosferze, obrabiała swoje zdjęcia w Photoshopie, oglądała księżycowe krajobrazy i pilotowała wirtualne samoloty wojskowe" [s. 70]. Im dłużej Faludi tam przebywa, tym mocniej pragnie opuścić tę wirtualną przestrzeń i znaleźć się w mieście - jak ma nadzieję - miejscu realnym. Gdy wreszcie tam jadą, córka odczuwa i ulgę, i rozczarowanie zarazem. Tak komentuje wizytę w Zamku Królewskim: 
Cieszyłam się. Nie tylko przekonałam ją, by opuściła własny zamek na wzgó$\mathrm{rzu}$, ale i sprawiłam, że oglądałyśmy pałac, gdzie zgromadzone zostały ślady jej przeszłości - a w każdym razie przeszłości jej narodu. Albo przynajmniej przeszłości, którą ten naród chciał mieć, jako że jego historia była tak samo spowita woalem fantazji, jak przeszłość mojego ojca [s. 80].

Budapeszt okazuje się zatem sztuczną konstrukcją - tak Faludi postrzega słynne Wzgórze Zamkowe: „Obecnie jest to pretensjonalna pułapka na turystów [...]. Jest równie odległa od miasta, które chciałam zobaczyć, jak twierdza ojca" [s. 79].

Faludi wprost odnotowuje ścisły - jej zdaniem - związek metamorfozy własnego ojca i miejsc, w których się ona odbywa: „Transformacja miasta w dziwny sposób przypominała przemianę mojego ojca. Podobnie jak ona, próbowało narodzić się na nowo w zaawansowanym wieku" [s. 187]. Ta przemiana jest dokonywana kosztem wyrzeczenia się przeszłości realnej na rzecz skonstruowania innej, łatwiejszej do zaakceptowania, przyjemniejszej, ładniejszej. Tę nową wersję Faludi nazywa „wyczyszczoną i ocenzurowaną" [s. 189]. Jak zauważa:

Stefánie wydawała się aprobować tego rodzaju uniki i maskowanie. Budapeszt, który chciała mi pokazać, był tak samo wyczyszczony i wyretuszowany, pozbawiony rozdziału swojej historii, który pozostawił dziury po kulach na budynkach i jego charakterze. Często myślałam o komentarzu noblisty Imre Kertésza dotyczącym jego dawnego miasta: „Nic nie zostało przepracowane, wszystko zamalowano na jasne kolory. Budapeszt to miasto bez pamięci" [s. 188].

Zatem Faludi postrzega przemianę ojca poprzez przestrzeń, w której się ona dokonuje. Zarazem enigmatyczność tej metamorfozy, ciągła oscylacja między ujawnianiem i kamuflowaniem, odkrywaniem i maskowaniem, permanentny stan retuszu powoduje, że odbiera tę przestrzeń jako rodzaj nietrwałych dekoracji. Wrażenie braku ciągłości osoby, którą jest jej ojciec, kogoś ostentacyjnie pozbawiającego się przeszłości i będącego tworem labilnym, rzutuje z kolei na cały kontekst, w jakim ów nieokreślony proces się odbywa. Również Węgry przybierają w oczach Faludi kształt kraju nierzeczywistego. Wszechobecny lament nad postanowieniami traktatu $\mathrm{w}$ Trianon, pozbawiającego Węgry 2/3 dawnego terytorium i pozostawiającego miliony Węgrów poza granicami nowego państwa, odbierającego mu „wszystkie porty, osiemdziesiąt procent lasów i wszystkie kopalnie węgla, soli i srebra" [s. 86] ma swoje dobicie w plakatach, którymi obwieszony jest Budapeszt:

Mapa ta przedstawiała kraj jako okaleczony tors, otoczony czterema odciętymi kończynami. Obrońcy węgierskiego honoru nazywają Trianon „amputa- 
cją". "Zniszczyła ojczyznę", powiedziała Stefánie podniesionym głosem. „Pocięła jego ciało na kawałki!" "Jej", poprawiłam" [s. 86].

Faludi jest przyzwyczajona do owego językowego pomieszania, kłopotów ojca z zaimkami: „Było nieodłączną cechą mojego dzieciństwa. «Powiedz swojej matce, że na niego czekam» [...] Węgrzy słyną z mylenia płci w języku angielskim. Język węgierski nie różnicuje zaimków zgodnie z rodzajem gramatycznym" [s. 46]. Częścią tego pomieszania, zdaniem autorki, są węgierskie kłopoty z rzeczywistością, skłonność do ulegania fantasmagoriom odcinającym dostęp do traumatycznej przeszłości odbieranej jako okaleczenie i amputacja. Faludi tak komentuje zwiedzanie Galerii Narodowej: „Wszystko, na co patrzyłyśmy, wydawało się osobliwe, złowieszczo dekoracyjne - oblicze narodu jako montaż następujących po sobie fantazji" [s. 84]. Jednak absurdalnie wielki kamper, dom-forteca, budowany z fantazji Budapeszt i równie fantasmagoryczne oblicze Węgier to nie tylko miejsca, które opowiadają coś o metamorfozie Stefi. To one same stają się pochodną sposobu, w jaki autorka postrzega Stevena/Stefánie/ojca/rodzica. Nie jest pewna, co w niej autentyczne (cokolwiek by to miało znaczyć), a co jest dekoracją, fortyfikacją za którą, być może, tkwi ukryty ktoś, kto jest jej rodzicem.

Co oczywiste, W ciemni jest opowieścią o tożsamości - jej poszukiwaniu, maskowaniu, konstruowaniu, płynności i ostatecznie - enigmatyczności. Z całego zestawu możliwości w tym względzie Stefi jako pierwszą odrzuca żydowskość. Nic dziwnego zatem, że córka, zwiedzając rozmaite miejsca w Budapeszcie, świadectwa przeszłej wielkości Węgier, zadaje sobie pytanie: „Dlaczego nie odwiedziłyśmy żadnej synagogi?” [s. 83]. Stefánie zapytana o zmianę nazwiska z Friedman - bo zbyt żydowskie - na Faludi, odpowiada: " "Zmieniłam je, bo byłam Węgierką». Poprawiła się. "Jestem Węgierką. W stu procentach»" [s. 65]. W innym miejscu mówi: "Jestem węgierską patriotką" [s. 113]. Córka zaś komentuje:

Miałam słabe pojęcie, co to znaczy być Żydówką, ale byłam absolutnie pewna, że nią jestem. Mojemu ojcu na każdym kroku przypominano, że jest Żydem, a jednak był absolutnie pewny, że jego tożsamość polega na czymś innym [s. 65].

Taka identyfikacja i cała „kwestia żydowska” w opowieści Faludi wiąże się $\mathrm{z}$ najbardziej traumatycznym doświadczeniem $\mathrm{w}$ relacjach między ojcem a nastoletnią wtedy córką. Oto Susan, namówiona przez koleżankę, wybiera się na rozmowę z księdzem prowadzącym spotkania katolickiej młodzieży. Mówi o tym matce, która uznaje to za zabawne. Tego samego wieczoru do sypialni córki wpada ojciec: 
„To ja cię stworzyłem", wrzasnął, wywlekając mnie z łóżka. Złapał mnie za kark i zaczął walić moją głową o podłogę. Jego atak furii wydawał się dość bełkotliwy, ale jedno było jasne - nie chciał, żeby jego dziecko zostało katoliczką. „To ja cię stworzyłem”, powiedział, kiedy moja głowa uderzała o podłogę. „I ja mogę cię zniszczyć". W ten sposób pewna córka dowiedziała się, że jej ojciec jest Żydem [s. 253].

Steven Faludi, pieczołowicie obchodzący Boże Narodzenie, reaguje na potencjalną konwersję swego wychowywanego w areligijnej właściwie rodzinie dziecka $\mathrm{z}$ iście starotestamentową furią: to gniew proroka pewnego swoich racji. Po latach Stefánie powie do córki w synagodze w Budapeszcie, pamiętając zresztą zupełnie inaczej swoje ówczesne słowa: „Nie powinnam była się tak wściekać” [s. 384], a córka, ściskając jej nadgarstek odpowie: „W porządku" [s. 385].

Kiedy oboje Faludi odwiedzają Węgierskie Muzeum Narodowe, okazuje się, że $\mathrm{w}$ małym, położonym $\mathrm{w}$ podziemiach pokoju bez okien znajduje się wystawa poświęcona zagładzie węgierskich Żydów. Zagładzie najskuteczniejszej w Europie, bo obejmującej niemal całą populację, dokonanej w dużej mierze przy wsparciu rodaków, co jest $\mathrm{w}$ węgierskiej polityce historycznej skrzętnie wymazywane, przemilczane, nie przystaje bowiem do martyrologicznego wizerunku Węgier: ojczyzny o okaleczonym ciele. Stefánie jest wyraźnie poruszona tą ekspozycją. Gdy z niej wychodzą, nie może powstrzymać się od komentarza:

„Ale mieć wystawę w Muzeum Narodowym! Fantastyczne. To bardzo ważne". Po kilkunastu metrach, jakby odpowiadając na własne słowa: „Nooo, ale jest w piwnicy". Wydała pogardliwe chrząknięcie. „Gdyby mieli księgę gości, napisałabym w niej: «Bardzo dziękuję! Dziękuję za umieszczenie Żydów w piwnicy!»" [s. 395].

Ze strony Stefánie to tyleż pośrednia identyfikacja z "Żydami w piwnicy", co jednoczesne przyznanie się do niezgody na wymazanie tego fragmentu przeszłości Węgier, uznanie granicy, poza którą retusz staje się czymś więcej niż korektą niedoskonałego obrazu. To też reakcja kogoś, kto wpadł w furię, gdy dowiedział się, że jego córka chce zgłosić akces do grona tych, którzy w mniemaniu Stefánie - są odpowiedzialni za zniknięcie wspólnoty, z którą ostatecznie czuje powinowactwo. Może poprzez niezgodę na przemilczenie i wymazanie tej części przeszłości.

Jednym z miejsc, do których udaje się Steven Faludi, uciekając przed skutkami własnej historyczno-geograficznej identyfikacji, jest Brazylia. Z perspektywy czasu nie tylko jemu, ale i córce kraj ten wydaje się dawać nieskończone możliwości i wolność od dokonywania takich właśnie tożsamo- 
ściowych wyborów. Jednak decyduje się wrócić do świata, z którego uciekł - jedzie do Stanów Zjednoczonych. Po latach córka usiłuje dociec, dlaczego się na to zdecydował:

Mnie narzuca się inne pytanie: dlaczego opuścił Brazylię? Umknął z miejsca, gdzie tożsamość oznaczała śmierć, do jednego z najbezpieczniejszych miejsc na Ziemi; ze świata wymuszanych, tragicznych podziałów rasowych do kraju, gdzie ich nie było. Jeśli tożsamość jest kwestią wyboru, a nie tym, przed czym nie da się uciec, przyjazd ojca do Rio zapoczątkował w jego życiu etap, gdy dostępne były dla niego wszelkie możliwe wybory zawodowe, religijne, rasowe i seksualne. Był wolny, nawet bardziej niż wolny. Mógł być w ciągłym ruchu [s. 299].

Okazuje się, że ojciec wraca dla kobiety, węgierskiej Żydówki, która ocalała z marszu śmierci. Faludi ma nadzieję, że wspólnie ułożą sobie życie. Twierdzi, że nie umiałby być z kimś wychowanym „w odmiennym kraju i środowisku" [s. 299]. Okazuje się, że jego wybranka ma już innego narzeczonego. Pośrednio zatem István/Steven/Stefánie przyznaje, że nie jest w stanie egzystować poza pewną wspólnotą oznaczającą przynajmniej częściowy akces do jakiegoś porządku identyfikacyjnego. Przyzna to bardzo wyraźnie w rozmowie z córką:

„Teraz jestem całkowicie jak kobieta”. Całkowicie kobietą, pomyślałam, czy całkowicie jak? „Trzeba się pozbyć starych nawyków. Jeśli się tego nie zrobi, będzie się całe życie obcym, będzie się tkwić w tym" - szukała właściwych słów „tym lęku przed brakiem przynależności". Powtórzyła: lęku przed brakiem przynależności. [...] „To byłby dobry tytuł dla twojej książki”, powiedziała. Wstała i zaczęła zbierać naczynia. „Z powrotem do kuchni!”, zawołała, wychodząc. „Tam jest miejsce kobiety” [s. 92].

Zatem ucieczka ojca, którą Faludi śledzi, jest tyleż chęcią uwolnienia się od pewnego usytuowania $\mathrm{w}$ świecie, co też wynikiem nieposkromionej potrzeby włączenia się w jakiś porządek, chęci odnalezienia miejsca wspólnego, możliwego do dzielenia z innymi. Owa przynależność może być okupiona koniecznością podporządkowania się stereotypom, wszak to one konstruują przestrzeń społecznego bezpieczeństwa i pewności. Stefánie mówi o tym wprost:

„Tożsamość to" - zawahała się - „rola, w jakiej zaakceptuje cię społeczeństwo. Trzeba się zachować tak, żeby ludzie cię akceptowali, inaczej narobisz sobie wrogów. Ja to właśnie robię - i nie mam żadnych problemów" [s. 344].

W innym miejscu Stefi dopowiada: „Teraz, kiedy jestem damą, wszyscy są dla mnie bardzo mili" [s. 31]. Kiedy Faludi rozmawia z kilkoma transseksualnymi kobietami, jedna z nich wyznaje, że żałuje swojej decyzji. Wprawdzie 
zrealizowała swoje marzenia, ale "czas na powrót do rzeczywistości” [s. 138]. Straciła pracę, jest samotna, przeżywa kryzys. Pytana o swoją identyfikację, odpowiada:

Czuję, że jestem androgyniczny ${ }^{9}$, ale nie chcę taki być. [...] Ludzie nie mogą żyć bez kategorii. Nawet ludzie znajdujący się na marginesach potrzebują kategorii, żeby mogli mieć miejsce na tych marginesach. Trzeba mieć tożsamość [s. 139].

To kolejna odsłona lęku przed byciem pomiędzy, bez klarownego miejsca w wszechobecnym binarnym porządku.

Drogę Stefánie "ku” i zarazem "od" pewnych autoidentyfikacji kończy choroba - zapada na demencję, choć zdaje się w dalszym ciągu uciekać. Dopada ją nie tyle rozpad, co wszystkie konstrukcje, które były jej dane lub te, które stworzyła. Córka jest tego „świadkinią", jak zaznaczyła na początku swojej opowieści:

Mówi się, że demencja to rozkład ja, powolne wyciekanie tożsamości. Kiedy tamtej zimy patrzyłam, jak ogarnia mojego ojca, uznałam, że jest raczej czymś przeciwnym: gwałtowną powodzią wszystkiego, czym była, czego doświadczyła i co czuła. [...] Jej umysł wydawał się podobny do piaskowca pod Wzgórzem Zamkowym: wydrążony przez to, co przez całe lata podmywało go od dołu. [...] Jeśli demencja jest tym, od czego nie sposób uciec, demencja Stefánie nadała jej tożsamości skoncentrowaną postać, nieubłaganą jak lawina [s. 403-404].

Jednak najsilniejszy okaże się strach przed konsekwencjami rozpoznania w dwóch wcieleniach - Stefánie zdradza córce, po tym, jak jej krzyki sprowadziły do domu najpierw policję, potem pogotowie: „Teraz widzę, kim oni są: typowi strzałokrzyżowcy. Myślą, że nie mam prawa być, kim jestem. Widzą mnie i myślą: "Żydówka»" [s. 404].

Ostatecznie ojciec Faludi umiera w szpitalu, który zdaniem córki wygląda jak „wiktoriański dom dla obłąkanych” [s. 406]. Gdy staje nad jego ciałem, uświadamia sobie, że w pewien sposób jej śledztwo dobiegło końca:

Spoglądałam w twarz mojego ojca, odwróconą teraz ode mnie, tak samo, jak często bywała za jej życia. Przez wszystkie dane jej lata próbowała odpowiedzieć sobie na pytanie, kim jest. Żydem czy chrześcijaninem? Węgrem czy Amerykaninem? Kobietą czy mężczyzną? Tak wiele przeciwieństw. Ale teraz, patrząc na jej martwe ciało, pomyślałam: jest tylko jeden prawdziwy podział, jedna rzeczywista dychotomia: życie i śmierć. Albo się żyje, albo nie. Wszystko inne jest płynne, plastyczne [s. 413].

\footnotetext{
${ }^{9}$ Polska tłumaczka, nieco niekonsekwentnie decyduje się tu na rodzaj męski. W oryginale zdanie to brzmi po prostu: „I feel I'm androgynous” [S. Faludi, In the Darkroom, s. 152].
} 
Kiedy Faludi zaczyna swoje śledztwo, zdaje się oczekiwać, że przyniesie ono rezultat dający się klarownie opisać. Zadaje pytania i chce jasnych odpowiedzi. Oczekuje, że wyłoni się jakiś spójny obraz uciekiniera/uciekinierki. Nic takiego się nie zdarza i autorka wyraźnie się z tym godzi:

W zrekonstruowanej ciemni wszystko pozostało takie, jak jesienią 2004, gdy Stefánie pokazywała mi cały dom. [...] Znowu wezwałam ślusarza i poprosiłam go o zmianę zamków w drzwiach na poddaszu. Przez tak długi czas chciałam za wszelką cenę rozgryźć zagadkę, jaką był mój ojciec. Teraz uznałam, że należy uszanować jej nieodgadnioność [s. 411-412].

Ostatecznie zatem uciekinier gubi ślady pogoni i nie zostaje przyłapany w piwnicy amerykańskiego domu, gdzie, jak pisze córka „projektował dekoracje, w których miało się rozgrywać życie naszej rodziny" [s. 21], ani w ciemni, gdzie dokonywał swoich mistrzowskich retuszy. Umyka kamperem-zigguratem do domu, katastrofy architektonicznej na wzgórzach Budy, domu, w którym zrekonstruował replikę amerykańskiej ciemni, teraz z całym elektronicznym Photoshopowym anturażem, w Budapeszcie, mieście dekoracji, na Węgrzech, kraju - fantasmagorii.

Faludi na początku swojej książki umieszcza, jako motto - jedno z trzech zresztą - cytat z Brzydkiego kaczątka Hansa Christiana Andersena. W tekście zastanawia się potem, na czym właściwie polega przemiana będąca tematem baśni: „jeśli kaczątko staje się łabędziem tylko dlatego, że rodzi się jako łabędź, jeśli Mała Syrenka pozwala rozdwoić sobie ogon po to tylko, by powrócić do morza, jakie właściwie przemiany obiecują te opowieści?" [s. 49]. Dowodzi, że w gruncie rzeczy opowieść o Istvánie/Stevenie/Stefánie Faludi jest tylko historią pewnego przypadku na skali perypetii autoidentyfikacyjnych, na której może nie każdy z nas zajmuje tak skrajne miejsce, niemniej wszyscy na niej - w pewnym czasie, w pewnych okolicznościach geograficzno-historycznych - gdzieś się lokujemy.

Paradoksalnie, na pewnym poziomie $W$ ciemni można uznać za wersję opowieści bio(geo)graficznej ${ }^{10}$. Budapeszt i Węgry, na mocy decyzji samego bohatera historii, którą rekonstruuje Faludi, stanowią przestrzenny kontekst dla możliwości interpretowania rozlicznych przemian jej ojca. Wspólny mianownik tej opowieści to nieustanny proces ujawniania i wymazywania, rekonstrukcji i dekonstrukcji. W przywoływanym zresztą przez Fajudi tekście, Susan Stryker, transseksualna kobieta pisze, iż jej ciało, jak w przypadku wszystkich osób w podobnej sytuacji, jako produkt zabiegów me-

10 Zob. E. Rybicka, Geopoetyka. Przestrzeń i miejsce we wspótczesnych teoriach i praktykach literackich, Kraków 2014, s. 107-111. 
dycznych jest nienaturalne $\mathrm{w}$ tym sensie, że nie $\mathrm{w}$ takiej postaci pojawiło się na świecie $\mathrm{w}$ chwili narodzin ${ }^{11}$. Zatem i tożsamość Stiepána/Stevena/Stefánie zdaje się być patchworkowym tworem godnym Victora Frankensteina, a jest rekonstruowana i dekonstruowana zarazem w fantasmagoryczno-realnej przestrzeni Budapesztu i na wyobrażonych Węgrzech - kadłubowych i okaleczonych.

Można szukać innych jeszcze porządków, w które wpisuje się niezwykła opowieść Faludi. A jest ona niezwykła z co najmniej dwóch powodów: dlatego, że historie tranzycji - przeciwnie niż ten tekst - przybierają najczęściej kształt autobiografii ${ }^{12}$, z kolei zaś fillial narratives raczej nie bywają próbami rekonstrukcji biografii ojców czy matek, którzy dokonali aż takiej metamorfozy, jak bohater $W$ ciemni. Niemniej tekst Faludi bez wątpienia można również uznać za swoistą literaturę postpamięciową, aczkolwiek, jeśli przywołać Marianne Hirsch określającą postpamięć jako:

doświadczenia tych, którzy dorastali w środowisku zdominowanym przez narracje wywodzące się sprzed ich narodzin. Ich własne, spóźnione historie ulegają zniesieniu przez historie poprzedniego pokolenia ukształtowane przez doświadczenie traumatyczne, których nie sposób ani zrozumieć, ani przetworzyć ${ }^{13}$.

to należałoby uznać $W$ ciemni za zapis obcowania właśnie $\mathrm{z}$ taką narracją szczątkową, ułomną, niemożliwą do wypowiedzenia opowieścią o traumie poprzedniego pokolenia. Faludi usiłuje zrekonstruować przeszłość ojca i dziadków, choć Stefánie uparcie twierdzi, że to historia kogoś, kim ona już nie jest, a to, czym dzieli się z nią Steven, córka określa jako: „raczej migawki niż historie, pozbawione narracji wizualne szrapnele, które wstrząsnęły moją dziecięcą wyobraźnią" [s. 35]. W pewnym aspekcie mamy tu do czynienia z kategorią "pamięci podziurawionej" użytą przez Henri'ego Raczymowa, a opisywaną przez Annę Ciarkowską następująco:

11 "The transsexual body, is an unnatural body. It is the product of medical science. It is a technological construction. It is flesh torn apart and sewn together again in a shape other than that in which it was born. In these circumstances, I find a deep affinity between myself as a transsexual woman and the monster in Mary Shelley's Frankenstein" [S. Stryker, My Words to Victor Frankenstein above the Village of Chamounix: Performing Transgender Rage, w: The Transgender Studies Reader, red. S. Stryker, S. Whitle, New York/London 2006, s. 245].

12 Zob. na przykład B.L. Hausman, Body, Technology, and Gender in Transsexual Autobiographies, w: The Transgender Studies Reader. W Polsce najgłośniejszą opowieścią autobiograficzną o doświadczeniu transseksualności była książka Kingi Kosińskiej Brudny róż. Zapiski z życia, którego nie było, Warszawa 2015.

${ }^{13}$ M. Hirsch, Żałoba i postpamięć, przeł. K. Bojarska, w: Teorie wiedzy o przeszłości na tle wspótczesnej humanistyki, red. E. Domańska, Poznań 2010, s. 254. 
to właśnie relacja między „przemilczanym” a „opowiedzianym” jest istotą koncepcji „pamięci podziurawionej”, szczególnie zaś sam proces zanikania opowieści, która zmienia się w milczenie - staje się pustką. To wokół niej rozbudowuje się struktura postpamięci; ona zmusza do zadania pytania: po czym jest ta pustka? ${ }^{14}$.

W pewnym sensie $W$ ciemni jest zatem próbą odpowiedzi na to pytanie, opowieścią o miejscu po Istvánie Friedmanie i Stevenie Faludi i zjawiającej się obok/zamiast historii Stefánie. To historia Stefi - damy, węgierskiej patriotki, dla której wszyscy są teraz mili. To też opowieść o miejscach, które te zniknięcia, metamorfozy, nieoczekiwane zjawianie się określają, współtworzą.

Kiedy w finale książki Susan Faludi pisze, iż zdecydowała się zamknąć na klucz budapeszteńską wersję nowojorskiej ciemni ojca, uznaje tym samym tajemnicę, jaką był za „nieodgadnioną”. To kończy naszą lekturę tekstu będącego fascynującym sprawozdaniem ze śledztwa, które autorka uważa za zwieńczone niepowodzeniem. Mogłoby się wydawać, że dzieje bohatera opowieści Faludi są wyjątkowo skomplikowane i uwikłane w najbardziej traumatyczne i tym samym ekstremalne doświadczenia historyczne i egzystencjalne, jakie mogły się przydarzyć człowiekowi w ostatnim stuleciu. Jednak to, iż W ciemni jest książką fascynującą nie wynika z owych skrajności wpisanych w losy obojga bohaterów (bo to przecież i o autorce opowieść). Bierze się to raczej z tego, że łatwo je odebrać jako pewien punkt - może skrajny właśnie - ale na tej samej skali, na której dają się ulokować perypetie tożsamościowe każdego z nas, bez względu na łatwość, z jaką wchodzimy w role, w których się obsadzamy, lub też umieszczają nas w nich inni. Łatwo też potraktować ten tekst jako rekonstrukcję starań, by rozpoznać i oswoić obcość najbliższych nam ludzi. Bo choć istnieje jedyny niepodważalny binarny porządek - jesteśmy albo żywi albo martwi, póki należymy do tej pierwszej kategorii wszyscy egzystujemy w nieokreślonych powikłaniach tożsamościowego "pomiędzy".

\section{Bibliografia}

Bianco Marcie, Identity Is a Battlefield - And Always a Negotiation, http://signsjournal. org/in-the-darkroom/\#bianco.

Ciarkowska Anna (2015), Kto ma pamięć podziurawioną? O koncepcji postpamięci według Henriego Raczymowa, „Politeja” nr 3, s. 189-199.

14 A. Ciarkowska, Kto ma pamięć podziurawioną? O koncepcji postpamięci wedtug Henriego Raczymowa, „Politeja” 2015, nr 3, s. 191-192. 
Couser G. Thomas (2012), Memoir: An Introduction, Oxford: Oxford University Press. Faludi Susan (2017), In the Darkroom, Londyn: William Collins.

Faludi Susan (2017), W ciemni, przeł. J. Bednarek, Warszawa: Wydawnictwo Krytyki Politycznej.

Hausman Bernice L. (2006), Body, Technology, and Gender in Transsexual Autobiographies, w: The Transgender Studies Reader, red. S. Stryker, S. Whitle, New York/London: Routledge, s. 335-361.

Hirsch Marianne (2010), Żałoba i postpamięć, przeł. K. Bojarska, w: Teorie wiedzy o przeszłości na tle współczesnej humanistyki, red. E. Domańska, Poznań: Wydawnictwo Poznańskie, s. 247-280.

Pitz Marylynne (2018), Susan Faludi discussed her book 'In the Darkroom' as part of Pittsburgh Arts \& Lectures' Ten Evenings series, https://www.post-gazette.com/ae/ books/2018/02/20/Susan-Faludi-Steven-Faludi-Stefanie-Faludi-In-the-Darkroom /stories/201802190009.

Rybicka Elżbieta (2014), Geopoetyka. Przestrzeń i miejsce we współczesnych teoriach i praktykach literackich, Kraków: Universitas.

Stryker Susan (2006), My Words to Victor Frankenstein above the Village of Chamounix: Performing Transgender Rage, w: The Transgender Studies Reader, red. S. Stryker, S. Whitle, New York/London: Routledge, s. 244-256.

Sunmer Jane (2016), Susan Faludi's "In the Darkroom” provides a stunning look at a complex man who became a woman - and was also her father, "The Dallas Morning News", https://www.dallasnews.com/arts/books/2016/07/15/susan-faludisdarkroom-provides-stunning-look-complex-man-became-woman-also-father.

\title{
In the Darkroom by Susan Faludi as a Story about a Journey to "In-between"
}

\begin{abstract}
The article analyzes In the Darkroom by Susan Faludi as representing filial narratives - biographies of a parent reconstructed and told by a son or a daughter, as well as post-memory literature - a reflection of the inherited trauma mediated by generational successors. The text demonstrates spatial entanglements in which the author's father made his metamorphosis: from a Hungarian Jew, István Friedman, through an American photographer Steven Faludi, to a Hungarian woman, pensioner and patriot Stefánie Faludi. Thus, the paper reconstructs the threads present in this book a combination of geographical and historical contexts determining the individual identity choices made by each of us.
\end{abstract}

Keywords: filial narratives, post-memory literature, biography, identity, transition 